\title{
The Role of Unknown Risk Factors in Myocardial Infarction
}

\author{
Rafighdoust Abbas Alia, d, Mirzaee Asadollah ${ }^{\mathrm{b}}$, Rafigdoust Amir Hossien ${ }^{\mathrm{c}}$
}

\begin{abstract}
Background: Atherosclerosis of coronary arteries is the most common cause of myocardial infarction (MI), which is initiated from childhood and progresses gradually by aging. Several risk factors influence its progress, and are categorized as classic, traditional and novel factors. The role of unknown risk factors is becoming increasingly more significant recently. The aim of this study is to underscore the novel risk factors despite the importance of classic factors and consider these factors for future studies.
\end{abstract}

Methods: This is a prospective study on 180 myocardial infarction cases, conducted in the cardiology ward and CCU of Imam-Reza hospital (Mashad-IRAN). A number of risk factors identified and evaluated in these patients included: hyperlipidemia, hypertension, diabetes, smoking, activity, stress, hair of external ear canal and ear lobe crease, age, and sex. Then patients without any risk factor or with one or two risk factors were distinguished.

Results: The majority of our patients were old men in the age range of 60 - 69 years. Amongst all patients $42.2 \%$ were smokers, $68.3 \%$ were type A personality group, $19 \%$ were active, $81 \%$ were physically inactive, $37.2 \%$ had hairy ear canal, $35 \%$ had hypertension, $21.1 \%$ were diabetic, $14.4 \%$ had hyperlipidemia and $30 \%$ had positive family history of myocardial infarction. Of great interest was the fact that of the patients whose case was studied, many did not have any risk factor or in some cases had only one.

Conclusions: In regard of increasing rate of cardiovascular diseases and myocardial infarction even amongst the young population, and

Manuscript accepted for publication November 22, 2010

${ }^{a}$ Cardiology department, Imam Reza hospital, Mashhad University of Medical Sciences, Mashhad, Iran

${ }^{\mathrm{b}}$ Cardiac surgery department, Ghaeem hospital, Mashhad University of Medical Sciences, Mashhad, Iran

${ }^{\mathrm{c} I n t e r n a l ~ M e d i c i n e, ~ Z a h e d a n ~ U n i v e r s i t y ~ o f ~ M e d i c a l ~ S c i e n c e s, ~ M a s h h a d, ~}$ Iran

${ }^{\mathrm{d}}$ Corresponding author, Email: abbasali_rafighdoust@yahoo.com

doi: $10.4021 / \mathrm{cr} 103 \mathrm{e}$ because of considerable need to improve vascular risk detection, much research over the past decade has focused on identification of novel atherosclerotic risk factors, and some of these new risk factors are identified and some may be unknown. Amongst the new risk factors, inflammation has an important role, other risk factors that must be assessed are homocysteine, serum amyloid, and antibodies against Oxidized LDL. So we recommend that governments and heart associations must introduce new plans and policies in order to tackle the problem and reduce the frequency of cardiovascular disease. This requires the understanding of the conventional or classic risk factors and also the less known and new risk factors and ways which they may be prevented.

Keywords: Myocardial infarction; Risk factors; Arteriosclerosis; Inflammation

\section{Introduction}

Atherosclerosis is the most common cause of ischemic heart diseases (IHD) that is initiated from childhood (Fatty Streak) and progresses gradually.

Several factors impact its progression, a number of which are classic or traditional factors and some unknown.

Classic or traditional risk factors include hyperlipidemia, hypertension, smoking, diabetes and metabolic syndrome.

Nevertheless, patients with ischemic heart disease are encountered without presenting any of the named risk factors in clinic. The question which arises is thus: what is the predisposing factor for atherosclerosis in these patients?

In an attempt to investigate this question we decided to evaluate patients with myocardial infarction (MI) who are without any classic risk factors.

\section{Materials and Methods}

This is a prospective study of 180 acute MI patients conducted in the cardiology ward and CCU of Imam Reza and Ghaem hospitals. The first aim was the evaluation and identification of classic risk factors, and the second was the assessment of those patients without any known risk factor. 
Patients were thus divided into different age groups, and age and sex distribution of MI was evaluated.

Classic risk factors included age, hyperlipidemia, hypertension, diabetes, smoking, physical activity, familial history of MI, and finally ear canal hair and ear lobe crease.

\section{Results}

Among the $180 \mathrm{MI}$ patients, $70.6 \%$ were male and $32.1 \%$ were aged between 60 and 69 years (Table 1).

Seventy-six patients (42.2\%) were smoker (Table 2) and Type A personality was seen in 123 patients (68.3\%) (Table 3 ). Physical activity as daily exercise was seen only in 33 cases $(18.3 \%)$ but poor physical activity was reported in 147

Table 1. Age and Sex Distribution in MI Cases

\begin{tabular}{llll}
\hline Age Group & $\begin{array}{l}\text { Total } \\
\text { N (\%) }\end{array}$ & $\begin{array}{l}\text { Female } \\
\text { N (\%) }\end{array}$ & $\begin{array}{l}\text { Male } \\
\text { N (\%) }\end{array}$ \\
\hline $20-29$ & $3(1.7 \%)$ & $0(0.0 \%)$ & $3(100 \%)$ \\
$30-39$ & $7(3.9 \%)$ & $1(14.3 \%)$ & $6(85.7 \%)$ \\
$40-49$ & $23(12.8 \%)$ & $5(21.7 \%)$ & $18(78.3 \%)$ \\
$50-59$ & $48(26.7 \%)$ & $11(22.9 \%)$ & $37(77.08 \%)$ \\
$60-69$ & $58(32.1 \%)$ & $20(34.5 \%)$ & $38(65.5 \%)$ \\
$70-79$ & $34(18.9 \%)$ & $15(44.1 \%)$ & $19(55.9 \%)$ \\
$80-89$ & $7(3.9 \%)$ & $1(14.3 \%)$ & $6(85.9 \%)$ \\
Sum & $180(100 \%)$ & $53(29.4 \%)$ & $127(70.6 \%)$ \\
\hline
\end{tabular}

Table 2. Smoking in Different Age Groups

\begin{tabular}{llll}
\hline $\begin{array}{l}\text { Age } \\
\text { Group }\end{array}$ & $\begin{array}{l}\text { Yess than 10 } \\
\text { Nears Smoking }\end{array}$ & $\begin{array}{l}\mathbf{1 0}-\mathbf{2 0} \text { Years } \\
\text { Smoking } \\
\mathbf{N}(\%)\end{array}$ & $\begin{array}{l}\text { More than 20 } \\
\text { Years Smoking } \\
\mathbf{N}(\%)\end{array}$ \\
\hline $20-29$ & $2(14.3 \%)$ & $0(0.0 \%)$ & $0(0.0 \%)$ \\
$30-39$ & $1(7.1 \%)$ & $1(7.7 \%)$ & $2(4.2 \%)$ \\
$40-49$ & $3(21.4 \%)$ & $4(30.8 \%)$ & $4(8.3 \%)$ \\
$50-59$ & $2(14.3 \%)$ & $4(30.8 \%)$ & $12(25 \%)$ \\
$60-69$ & $3(21.4 \%)$ & $2(15.4 \%)$ & $18(37.5 \%)$ \\
$70-79$ & $3(21.4 \%)$ & $1(7.7 \%)$ & $11(22.9 \%)$ \\
$80-89$ & $0(0.0 \%)$ & $1(7.7 \%)$ & $1(2.08 \%)$ \\
Sum & $14(18.4 \%)$ & $13(17.1 \%)$ & $48(63.1 \%)$ \\
\hline
\end{tabular}

cases $(81.7 \%)$ (Table 4). Ear canal hair was seen in 67 patients $(37.2 \%)$ and 8 cases $(4.4 \%)$ had helical fold and both were reported in 7 cases $(4 / 2 \%)$ (Table 5$)$.

Thirty-eight patients $(21.1 \%)$ were diabetic and hyper-

Table 3. Frequency of Stress in Different Age Groups

\begin{tabular}{lll}
\hline Age Group & $\begin{array}{l}\text { Number of Patients } \\
\text { With Stress }\end{array}$ & Percentage \\
\hline $20-29$ & 3 & 2.4 \\
$30-39$ & 6 & 4.9 \\
$40-49$ & 19 & 15.4 \\
$50-59$ & 34 & 27.6 \\
$60-69$ & 37 & 30.08 \\
$70-79$ & 20 & 16.3 \\
$80-89$ & 4 & 3.3 \\
Sum & 123 & 68.3 \\
\hline
\end{tabular}

Table 4. Physical Activity in Different Age Groups

\begin{tabular}{lll}
\hline Age Group & $\begin{array}{l}\text { Number of Patients } \\
\text { With Physical Activity }\end{array}$ & Percentage \\
\hline $20-29$ & 0 & 0.0 \\
$30-39$ & 2 & 6.06 \\
$40-49$ & 5 & 15.2 \\
$50-59$ & 14 & 42.4 \\
$60-69$ & 7 & 21.2 \\
$70-79$ & 5 & 15.2 \\
$80-89$ & 0 & 0.0 \\
\hline
\end{tabular}

Table 5. Ear Canal Hair and Helical Fold in Different Age Groups

\begin{tabular}{llll}
\hline $\begin{array}{l}\text { Age } \\
\text { Group }\end{array}$ & $\begin{array}{l}\text { Hairy Ear Canal } \\
\text { N (\%) }\end{array}$ & $\begin{array}{l}\text { Helical Fold } \\
\text { N (\%) }\end{array}$ & $\begin{array}{l}\text { Both } \\
\text { N (\%) }\end{array}$ \\
\hline $20-29$ & - & $0(0.0 \%)$ & - \\
$30-39$ & $2(3 \%)$ & $0(0.0 \%)$ & $1(5.9 \%)$ \\
$40-49$ & $9(13.4 \%)$ & $0(0.0 \%)$ & $1(5.9 \%)$ \\
$50-59$ & $19(28.3 \%)$ & $4(50 \%)$ & $1(5.9 \%)$ \\
$60-69$ & $19(28.3 \%)$ & $3(37.5 \%)$ & $7(41.2 \%)$ \\
$70-79$ & $15(22.4 \%)$ & $1(12.5 \%)$ & $6(35.3 \%)$ \\
$80-89$ & $3(4.5 \%)$ & $0(0.0 \%)$ & $1(5.9 \%)$ \\
Sum & $67(37.2 \%)$ & $8(4.4 \%)$ & $17(9.4 \%)$ \\
\hline
\end{tabular}


tension was seen in $35 \%$ (Table 6,7 ).

Lipid profile in 20 - 39 year age group showed some cases with cholesterol level higher than $200 \mathrm{mg} / \mathrm{dl}$, and $17 \%$ of patients in 40 - 89 year age group had cholesterol level higher than $200 \mathrm{mg} / \mathrm{dl}$ (Table 8).

LDL level in all patients with the age of 20 - 39 years was lower than $160 \mathrm{mg} / \mathrm{dl}$ but $35 \%$ of 40 - 80 year age group had higher than $160 \mathrm{mg} / \mathrm{dl}$ (Table 9).

Finally, positive family history was seen in 55 patients (30.5\%) (Table 10).

Combination of risk factors including hyperlipidemia, hypertension, diabetes and smoking were not reported in

Table 6. Frequency of DM in Different Age Groups

\begin{tabular}{lllll}
\hline Age Group & $\begin{array}{l}\text { Total Diabetic Patients } \\
\text { N (\%) }\end{array}$ & $\begin{array}{l}\text { DM for } \\
\mathbf{0}-\mathbf{1 0} \text { Years N (\%) }\end{array}$ & $\begin{array}{l}\text { DM for } \\
\mathbf{1 0}-\mathbf{2 0} \text { Years N (\%) }\end{array}$ & $\begin{array}{l}\text { DM of More than 20 } \\
\text { Years N }(\%)\end{array}$ \\
\hline $20-29$ & $0(0.0 \%)$ & $0(0.0 \%)$ & $0(0.0 \%)$ & $0(0.0 \%)$ \\
$30-39$ & $1(2.6 \%)$ & $1(3.4 \%)$ & $0(0.0 \%)$ & $0(0.0 \%)$ \\
$40-49$ & $2(5.3 \%)$ & $2(6.9 \%)$ & $0(0.0 \%)$ & $0(0.0 \%)$ \\
$50-59$ & $11(28.9 \%)$ & $10(34.5 \%)$ & $6(12.5 \%)$ & $1(100 \%)$ \\
$60-69$ & $19(50.0 \%)$ & $12(41.4 \%)$ & $1(12.5 \%)$ & $0(0.0 \%)$ \\
$70-79$ & $5(13.1 \%)$ & $4(3.8 \%)$ & $0(0.0 \%)$ & $0(0.0 \%)$ \\
$80-89$ & $0(0.0)$ & $0(0.0 \%)$ & $8(21.5 \%)$ & $1(2.6 \%)$ \\
\hline
\end{tabular}

Table 7. Frequency of Htn in Different Age Groups

\begin{tabular}{lll}
\hline Age Group & $\begin{array}{l}\text { Number of } \\
\text { Hypertensive Cases }\end{array}$ & Percentage \\
\hline $20-29$ & 0 & 0.0 \\
$30-39$ & 0 & 0.0 \\
$40-49$ & 4 & 6.3 \\
$50-59$ & 13 & 20.6 \\
$60-69$ & 26 & 41.3 \\
$70-79$ & 17 & 26.9 \\
$80-89$ & 3 & 4.8 \\
Sum & 63 & 35 \\
\hline
\end{tabular}

Table 9. LDL Level in Different Age Groups

\begin{tabular}{lll}
\hline Age Group & LDL $\geq \mathbf{1 6 0 m g / d l ~ ( \% )}$ & LDL $<\mathbf{1 6 0 m g / d l ~ ( \% ) ~}$ \\
\hline $20-29$ & 0 & 100 \\
$30-39$ & 0 & 100 \\
$40-49$ & 35 & 65 \\
$50-59$ & 29 & 71 \\
$60-69$ & 20 & 80 \\
$70-79$ & 27 & 73 \\
$80-89$ & 31 & 69 \\
\hline
\end{tabular}

Table 8. Cholesterol Level in Different Age Groups

\begin{tabular}{lll}
\hline Age Group & $\begin{array}{l}\text { Chol } \geq \mathbf{2 0 0 m g / d l} \\
(\%)\end{array}$ & $\begin{array}{l}\text { Chol }<200 \mathbf{m g} / \mathbf{d l} \\
(\%)\end{array}$ \\
\hline $20-29$ & 0 & 100 \\
$30-39$ & 0 & 100 \\
$40-49$ & 17 & 83 \\
$50-59$ & 17 & 83 \\
$60-69$ & 16 & 84 \\
$70-79$ & 15 & 85 \\
$80-89$ & 0 & 100 \\
\hline
\end{tabular}

Table 10. Family History of IHD in Different Age Groups

\begin{tabular}{lll}
\hline Age Group & $\begin{array}{l}\text { Frequency of Positive } \\
\text { FH for IHD }\end{array}$ & Percentage \\
\hline $20-29$ & 2 & 3.6 \\
$30-39$ & 5 & 9.09 \\
$40-49$ & 9 & 16.4 \\
$50-59$ & 16 & 29.09 \\
$60-69$ & 16 & 29.09 \\
$70-79$ & 7 & 12.7 \\
$80-89$ & 0 & - \\
Sum & 55 & 30.5 \\
\hline
\end{tabular}


Table 11. Frequency of Patients Without Combination Risk Factors for IHD (Htn, HPL, DM and Smoking) in Different Age Groups

\begin{tabular}{lll}
\hline Age Group & $\begin{array}{l}\text { Patients Without Any } \\
\text { Risk Factor }\end{array}$ & Percentage \\
\hline $20-29$ & 3 & 100 \\
$30-39$ & 7 & 14 \\
$40-49$ & 23 & 17 \\
$50-59$ & 48 & 29 \\
$60-69$ & 58 & 18 \\
$70-79$ & 34 & 35 \\
$80-89$ & 7 & - \\
\hline
\end{tabular}

patients in the age range of 20 - 39 years, and these risk factors were seen on average in $25 \%$ of $30-89$ year age group (Table 11).

Lipid profile showed normal LDL and total Cholesterol in 20 - 39 year age group, and normal cholesterol and LDL level were reported respectively in $83 \%$ and $70 \%$ among those patients who aged 40 - 89 years (Table 8,9 ).

\section{Discussion}

Cardiovascular disease is the most common cause of mortality in developed countries and almost one million deaths are reported annually in the US because of ischemic heart diseases (IHD) [1]. In this study we evaluated atherosclerosis risk factors in two parts. The first part consisted of epidemiological study of classic or traditional risk factors.

Nevertheless, one must mention based on long term experience that myocardial infarction may also occur in people without any known risk factor. Hence we decided to evaluate the frequency of $\mathrm{MI}$ in patients without any risk factor as the second part of our study [2-5].

A prospective study of healthy American ladies reported that $77 \%$ of ischemic heart diseases have occurred in patient with LDL lower than $160 \mathrm{mg} / \mathrm{dl}$ and $46 \%$ have occurred in those with LDL lower than $130 \mathrm{mg} / \mathrm{dl}[1,6]$.

Another study showed that, although serum lipids have a great role in ischemic heart disease, half of patients with acute MI had normal lipid profile; and another study showed that $20 \%$ of ischemic heart diseases happened in the absence of any classic risk factor $[7,8]$.

Another study on known cases of ischemic heart disease did not show combination of risk factors including hyperlipidemia, hypertension, diabetes and smoking. In $15 \%$ of men, $19 \%$ of women and more than half of all patients had only one classic risk factor [9-11].
Finally, another study reported only one risk factor in $85-95 \%$ of ischemic heart disease cases [1-13].

Similarly, our study did not show combination of risk factors including hyperlipidemia, hypertension, diabetes and smoking in 20 - 29 year age group with MI, although it seems there should be a great risk factor for MI in young people.

This study showed that cholesterol was less that $200 \mathrm{mg} /$ $\mathrm{dl}$ in all cases in 20 - 39 year age group and only $17 \%$ of patients in 40 - 89 year age group had cholesterol level higher than $200 \mathrm{mg} / \mathrm{dl}$.

LDL level was also less than $160 \mathrm{mg} / \mathrm{dl}$ in all cases in 20 - 39 year age group and only $30 \%$ of those in $40-89$ year age group had LDL level higher than $160 \mathrm{mg} / \mathrm{dl}$. In 30 89 year age group, $25 \%$ of those were risk factor free. So it seems logical to detect other unknown risk factors for ischemic heart disease.

Besides genetic factors and coagulative disorders, inflammatory response becomes a new risk factor for ischemic heart disease. Inflammation without any origin or due to infection, air pollution and many other causes may promote atherosclerosis and this is of need of further studies yet [6, 12-15].

Other new risk factors include lipoprotein, homocysteine and fibrinolytic markers [13]. Fortunately, inflammatory markers are measurable and main markers including hsCRP, IL-6, P-selective sVCAM, CD40, and leukocyte activator agents such as Myeloperoxidase (MPO) could be measured exactly in laboratories [16-19].

\section{Conclusions}

In regard of increasing rate of cardiovascular diseases and myocardial infarction even amongst the young population, and because of considerable need to improve vascular risk detection, much research over the past decade has focused on identification of novel atherosclerotic risk factors, and some of these new risk factors are identified and some maybe unknown. Amongst the new risk factors, inflammation has been recently identified which maybe the result of infection, air pollution, or stress and the like, other risk factors that must be assessed are homocysteine, serum amyloid, and antibodies against Oxidized LDL. So we recommend that governments and heart associations must introduce new plans and policies in order to tackle the problem and reduce the frequency of cardiovascular disease. This requires the understanding of the conventional or classic risk factors and also the less known and new risk factors and ways which they may be prevented.

\section{References}

1. Zipe, Libby, Bonow, Branwald's Heart disease a text book of cardiovascular Med. Risk factor for Atheroscle- 
rosis. 2005, 7th ed, chapter 36, P:939-953.

2. Khot UN, Khot MB, Bajzer CT, Sapp SK, Ohman EM, Brener SJ, Ellis SG, et al. Prevalence of conventional risk factors in patients with coronary heart disease. JAMA 2003;290(7):898-904.

3. Greenland P, Knoll MD, Stamler J, Neaton JD, Dyer AR, Garside DB, Wilson PW. Major risk factors as antecedents of fatal and nonfatal coronary heart disease events. JAMA 2003;290(7):891-897.

4. Ridker PM. Evaluating novel cardiovascular risk factors: can we better predict heart attacks? Ann Intern Med 1999;130(11):933-937.

5. Hackam DG, Anand SS. Emerging risk factors for atherosclerotic vascular disease: a critical review of the evidence. JAMA 2003;290(7):932-940.

6. Pradhan AD, Manson JE, Rossouw JE, Siscovick DS, Mouton CP, Rifai N, Wallace RB, et al. Inflammatory biomarkers, hormone replacement therapy, and incident coronary heart disease: prospective analysis from the Women's Health Initiative observational study. JAMA 2002;288(8):980-987.

7. Libby P, Ridker PM, Maseri A. Inflammation and atherosclerosis. Circulation 2002;105(9):1135-1143.

8. Buffon A, Biasucci LM, Liuzzo G, D'Onofrio G, Crea F, Maseri A. Widespread coronary inflammation in unstable angina. N Engl J Med 2002;347(1):5-12.

9. Ridker PM. Clinical application of C-reactive protein for cardiovascular disease detection and prevention. Circulation 2003;107(3):363-369.

10. Jabs WJ, Theissing E, Nitschke M, Bechtel JF, Duchrow M, Mohamed S, Jahrbeck B, et al. Local generation of $\mathrm{C}$-reactive protein in diseased coronary artery venous bypass grafts and normal vascular tissue. Circulation 2003;108(12):1428-1431.

11. Pasceri V, Willerson JT, Yeh ET. Direct proinflammatory effect of C-reactive protein on human endothelial cells. Circulation 2000;102(18):2165-2168.
12. Paul A, Ko KW, Li L, Yechoor V, McCrory MA, Szalai AJ, Chan L. C-reactive protein accelerates the progression of atherosclerosis in apolipoprotein E-deficient mice. Circulation 2004;109(5):647-655.

13. Ridker PM, Stampfer MJ, Rifai N. Novel risk factors for systemic atherosclerosis: a comparison of C-reactive protein, fibrinogen, homocysteine, lipoprotein(a), and standard cholesterol screening as predictors of peripheral arterial disease. JAMA 2001;285(19):2481-2485.

14. Pearson TA, Mensah GA, Alexander RW, Anderson JL, Cannon RO, 3rd, Criqui M, Fadl YY, et al. Markers of inflammation and cardiovascular disease: application to clinical and public health practice: A statement for healthcare professionals from the Centers for Disease Control and Prevention and the American Heart Association. Circulation 2003;107(3):499-511.

15. O'Connor CM, Dunne MW, Pfeffer MA, Muhlestein JB, Yao L, Gupta S, Benner RJ, et al. Azithromycin for the secondary prevention of coronary heart disease events: the WIZARD study: a randomized controlled trial. JAMA 2003;290(11):1459-1466.

16. Ridker PM, Rifai N, Stampfer MJ, Hennekens CH. Plasma concentration of interleukin- 6 and the risk of future myocardial infarction among apparently healthy men. Circulation 2000;101(15):1767-1772.

17. Ridker PM, Hennekens CH, Roitman-Johnson B, Stampfer MJ, Allen J. Plasma concentration of soluble intercellular adhesion molecule 1 and risks of future myocardial infarction in apparently healthy men. Lancet 1998;351(9096):88-92.

18. Ridker PM, Buring JE, Rifai N. Soluble P-selectin and the risk of future cardiovascular events. Circulation 2001;103(4):491-495.

19. Zhang R, Brennan ML, Fu X, Aviles RJ, Pearce GL, Penn MS, Topol EJ, et al. Association between myeloperoxidase levels and risk of coronary artery disease. JAMA 2001;286(17):2136-2142. 